\title{
Acetylcholine Mediates the Estrogen-Induced Increase in NMDA Receptor Binding in CA1 of the Hippocampus and the Associated Improvement in Working Memory
}

\author{
Jill M. Daniel and Gary P. Dohanich \\ Department of Psychology, Tulane University, New Orleans, Louisiana 70118
}

Elevated levels of circulating estrogen in female rats result in increased spine and synapse density and parallel increases in NMDA receptor binding in area CA1 of the hippocampus. Estrogen also influences cholinergic neurochemistry in the basal forebrain and hippocampus. The objectives of the present study were to determine the role of acetylcholine in the estrogen-induced increase in NMDA receptor binding in CA1 of the hippocampus and to investigate the relationship between increased NMDA receptor binding in CA1 and performance on a task of working memory. In the current experiments, elevating endogenous levels of acetylcholine in ovariectomized rats by $3 \mathrm{~d}$ of continuous administration of physostigmine, an acetylcholinesterase inhibitor, increased NMDA receptor binding in CA1 as measured by quantitative autoradiography. This increase was comparable with the increase in NMDA receptor binding induced by injections of estradiol benzoate 72 and $48 \mathrm{hr}$ before death. Additionally, the administration of 5,11-dihydro-8-chloro-11-[[4-[3- [(2,2-dimethyl-1-oxopentyl)ethylamino]propyl]-1-piperidinyl]acetyl]6H-pyrido[2,3-b][1,4]benzodiazepin-6-one (BIBN 99), an M2 receptor antagonist, blocked the ability of both estrogen and physostigmine to increase NMDA receptor binding. The regimen of estradiol replacement that was demonstrated to increase NMDA receptor binding in CA1 of ovariectomized rats also improved arm-choice accuracy in a working memory task in an eight-arm radial maze. The estrogen-induced improvement in working memory performance was blocked by BIBN 99, which also blocked the increase in NMDA receptor binding. These results indicate that acetylcholine acts at M2 muscarinic receptors to mediate the estrogen-induced increase in NMDA receptor binding in CA1 of the hippocampus as well as the associated improvement in working memory.

Key words: estrogen; acetylcholine; hippocampus; learning; memory; NMDA receptors; M2 muscarinic receptors
The ovarian hormone estrogen affects performance on various measures of learning and memory in mammals, although the mechanisms underlying these effects are unknown. Estrogen induces morphological changes and modulates excitatory and inhibitory neurotransmission in the hippocampus, an area of the brain implicated in learning and memory. For example, spine and synapse density on CA1 pyramidal cells is positively correlated with estrogen levels, as indicated by experiments in which exogenous estrogen was manipulated (Gould et al., 1990) and in which estrogen levels varied across the rat estrous cycle (Woolley et al., 1990). Interestingly, estradiol-induced increases in spine density in CA1 correlated positively to increased NMDA but not AMPA receptor binding as well as to increased sensitivity of CA1 pyramidal cells to NMDA but not AMPA receptor-mediated synaptic input (Woolley et al., 1997). In addition to increasing the density of dendritic spines on pyramidal cells in vitro (Murphy and Segal, 1996), estradiol decreased levels of glutamic acid decarboxylase (GAD), the GABA-synthesizing enzyme, and decreased GABAergic miniature IPSCs (Murphy et al., 1998), indicating that estradiol-induced spine formation results from a disinhibi-

\footnotetext{
Received April 17, 2001; revised June 18, 2001; accepted June 19, 2001.

This research was supported by National Science Foundation Award IBN-9728901 (G.P.D.). We thank Jeffrey Puissegur and Ray Berryman for excellent animal husbandry, Zuzana Hruska for imaging assistance, and Drs. Paul Colombo, Jeffrey Tasker, and Beth Wee for helpful discussions throughout the course of this study. Correspondence should be addressed to Dr. Jill Daniel, Department of Pharmacology and Experimental Therapeutics, Louisiana State University Health Sciences Center, 1901 Perdido Street, New Orleans, LA 70112. E-mail: jdanie2@1suhsc.edu. Copyright (C) 2001 Society for Neuroscience $\quad 0270-6474 / 01 / 216949-\bullet \$ 15.00 / 0$
}

tion of hippocampal pyramidal cells that occurs after reduction of GABAergic inhibition.

Transection of the fimbria/fornix, which contains the majority of the subcortical afferents to the hippocampus, prevented an estradiol-induced increase in dendritic spine density on CA1 pyramidal cells (Leranth et al., 2000). The fimbria/fornix contains the cholinergic input to the hippocampus from the medial septal/ diagonal band complex (Paxinos, 1995). Estrogen facilitates cholinergic neurotransmission in the septal-hippocampal pathway as evidenced by its ability to increase activity and mRNA of choline acetyltransferase (Luine, 1985; Gibbs and Pfaff, 1992; Gibbs et al., 1994), high-affinity choline uptake (O'Malley et al., 1987; Singh et al., 1994), and acetylcholine release (Gibbs et al., 1997). Acetylcholine regulates hippocampal GABA release via action at the M2 subtype of the muscarinic receptor located on axon terminals of GABAergic basket and chandelier cells, interneurons that provide powerful input to pyramidal cells (Freund and Gulyas, 1997; Hajos et al., 1998). Thus, these presynaptically located M2 receptors provide a mechanism by which the estrogen-induced elevation of acetylcholine could reduce hippocampal GABA release resulting in disinhibition of CA1 pyramidal cells.

Although estrogen affects learning and memory performance, to date there are no published reports that associate the estradiolinduced changes in spine density and NMDA receptor binding in CA1 to improvements in performance on tasks that measure learning and memory. Estrogen impairs or has no effect on tasks dependent on spatial reference memory, defined as memory for information consistent across trials (Galea et al., 1995; Berry et 
al., 1997; Warren and Juraska, 1997; Daniel et al., 1999; Miller et al., 1999; Wilson et al., 1999; Chesler and Juraska, 2000). However, constant levels of estrogen present over a number of days or weeks enhance performance on tasks that are dependent on spatial working memory, defined as memory for information relevant for a single trial (O'Neal et al., 1996; Daniel et al., 1997; Fader et al., 1998, 1999; Bimonte and Denenberg, 1999; Gibbs, 1999, 2000; Wilson et al., 1999).

The objective of the current experiments was to determine whether estrogen regulates NMDA receptor binding in the hippocampus via its ability to influence cholinergic neurotransmission. Additionally, we determined whether the estradiol-induced increase in NMDA receptor binding was associated with enhancement in performance on a task of working memory.

\section{MATERIALS AND METHODS}

\section{Experiment 1}

Subjects. Twenty-seven Long-Evans hooded female rats, $\sim 60 \mathrm{~d}$ of age, were purchased from Harlan Sprague Dawley (Indianapolis, IN). Animal care was in accordance with guidelines set by the National Institutes of Health Guide for the Care and Use of Laboratory Animals (1996). Rats were housed individually in a temperature-controlled vivarium under a $12 \mathrm{hr}$ light/dark cycle (lights on at 7:00 A.M.). At $65 \mathrm{~d}$ of age, all rats were ovariectomized while under anesthesia induced by injection of ketamine $(100 \mathrm{mg} / \mathrm{kg}$, i.p.; Bristol Laboratories, Syracuse, NY) and xylazine (7 mg/kg, i.p.; Miles Laboratories, Shawnee, KS). Animals were randomly assigned to one of the following groups $(n=9)$ : (1) control, (2) physostigmine at $0.0075 \mathrm{mg} \cdot \mathrm{kg}^{-1} \cdot \mathrm{hr}^{-1}$, or (3) physostigmine at $0.06 \mathrm{mg} \cdot \mathrm{kg}^{-1} \cdot \mathrm{hr}^{-1}$.

Treatments. Three days after ovariectomy, rats were implanted subcutaneously with osmotic minipumps (Alza, Palo Alto, CA) containing physostigmine hemisulfate (Sigma, St. Louis, MO) in vehicle solution (10\% ethanol, $40 \%$ propylene glycol, and $50 \%$ distilled water) or sham pumps while under anesthesia induced by methoxyflurane (PitmanMoore, Mundelein, IL). The physostigmine implants maintained constant delivery rates of 0.0075 or $0.06 \mathrm{mg} \cdot \mathrm{kg}^{-1} \cdot \mathrm{hr}^{-1}$, doses that approximated the $\mathrm{ED}_{50}$ and near-maximal inhibition of cortical acetylcholinesterase activity, respectively (Mandel et al., 1989). To coincide with the duration of estradiol treatment demonstrated previously to increase NMDA receptor binding (Woolley et al., 1997), implants were left in place for $3 \mathrm{~d}$ before death by decapitation. Brains were rapidly removed, frozen on powdered dry ice, and stored at $-70^{\circ} \mathrm{C}$ until sectioning.

Receptor autoradiography. Frozen coronal sections, $20 \mu \mathrm{m}$ thick, were cut on a microtome cryostat, thaw-mounted on gelatinized slides, and stored at $-70^{\circ} \mathrm{C}$. Twelve consecutive sections were taken through the dorsal hippocampus of each brain, beginning at $2.56 \mathrm{~mm}$ posterior to bregma and extending to $2.80 \mathrm{~mm}$ posterior to bregma (Paxinos and Watson, 1998). NMDA receptor binding was determined according to Weiland (1992a). Slide-mounted sections were thawed, dried completely, and preincubated in slide mailers containing $10 \mathrm{ml}$ of $50 \mathrm{~mm}$ Tris-acetate

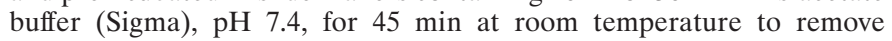
endogenous ligand. Sections were dried for $10 \mathrm{~min}$ under a stream of cool air. Six sections per brain were incubated in slide mailers containing 200 nм $\left[{ }^{3} \mathrm{H}\right]$ glutamate $(51.90 \mathrm{Ci} / \mathrm{mmol}$; NEN, Boston, MA) in Tris-acetate buffer, and six alternate sections per brain were incubated in Tris-acetate buffer containing $200 \mathrm{~nm}\left[{ }^{3} \mathrm{H}\right]$ glutamate plus $1 \mathrm{~mm}$ NMDA (Sigma). After incubation, sections were rinsed four times for $5 \mathrm{sec}$ each in ice-cold Tris-acetate buffer and dried rapidly. Sections were placed in contact with tritium-sensitive film (Hyperfilm; Amersham, Uppsala, Sweden) for $30 \mathrm{~d}$ with ${ }^{3} \mathrm{H}$-labeled plastic standards (Microscales; Amersham) that contained known quantities of radioactivity. Films were developed for $4 \mathrm{~min}$ in Kodak D-19 developer and fixed for $5 \mathrm{~min}$ in Kodak rapid-fix.

Quantitative analysis of receptor binding. Autoradiograms were analyzed by computer-assisted densitometry using NIH Image 1.61 software that measured relative optical density. The experimenter was blind to treatment conditions during imaging procedures. Measurements were taken for the entire CA1 region of the dorsal hippocampus (Weiland, 1992a; Cyr et al., 2000), because estrogen treatment increases NMDA receptor binding in both the stratum radiatum and stratum oriens of CA1 (Woolley et al., 1997). Optical density was converted to concentration of radioligand (picomoles per milligram of protein) on the basis of a standard curve generated from ${ }^{3} \mathrm{H}$-labeled plastic standards. To determine NMDA receptor binding, $\left[{ }^{3} \mathrm{H}\right]$ glutamate binding that remained in the presence of NMDA was subtracted from total $\left[{ }^{3} \mathrm{H}\right]$ glutamate binding. Previous work in this laboratory revealed an asymmetric distribution of hippocampal muscarinic receptors (Wolff et al., 1997). Therefore, to determine whether a similar asymmetry in the distribution of NMDA receptors was present, means were calculated for each hemisphere of each animal separately.

\section{Experiment 2}

Subjects. Forty Long-Evans female rats were obtained at $60 \mathrm{~d}$ of age and ovariectomized at $65 \mathrm{~d}$ of age. Housing conditions and surgical procedures were as described in Experiment 1. Animals were assigned to one of the following treatment groups $(n=10)$ : (1) control, (2) estrogen, (3) physostigmine, or (4) physostigmine + BIBN 99.

Treatments. Three days after ovariectomy, rats assigned to the physostigmine and the physostigmine + BIBN 99 groups were implanted subcutaneously with osmotic minipumps that maintained constant delivery rates of physostigmine at $0.06 \mathrm{mg} \cdot \mathrm{kg}^{-1} \cdot \mathrm{hr}^{-1}$, the dose demonstrated in Experiment 1 to increase NMDA receptor binding in CA1. Animals in the other two groups were implanted with sham pumps.

At the time that the minipumps were implanted, females assigned to the physostigmine + BIBN 99 group received injections of the M2 muscarinic receptor antagonist BIBN $99(0.05 \mathrm{mg} / \mathrm{kg}$, s.c.; provided by $\mathrm{K}$. Thomae GMBH, Biberach, Germany) delivered in $0.1 \mathrm{ml}$ of $4.2 \%$ aqueous D-mannitol solution. Additional injections of BIBN 99 were given every $4 \mathrm{hr}$ until animals were killed. This regimen of drug treatment was based on observations that the behavioral effects of a single injection of $0.05 \mathrm{mg} / \mathrm{kg} \mathrm{BIBN}-99$ are apparent for at least $4 \mathrm{hr}$ in rats (Quirion et al., 1995). Animals assigned to the other three treatment groups received vehicle injections every $4 \mathrm{hr}$ until death.

On days 3 and 4 after ovariectomy, animals assigned to the estrogen group were injected intramuscularly with $10 \mu \mathrm{g}$ (total dose) of estradiol benzoate (Sigma) in $0.1 \mathrm{ml}$ of cottonseed oil vehicle (Woolley et al., 1997). Animals assigned to the other three groups were injected with oil vehicle alone. Forty-eight hours after the second estradiol or oil vehicle injection, animals were killed by decapitation. Brains were rapidly removed, frozen on powdered dry ice, and stored at $-70^{\circ} \mathrm{C}$ until sectioning. NMDA receptor binding in area CA1 of the hippocampus was determined by quantitative receptor autoradiography as described in Experiment 1.

Summary. The schedule of treatment procedures for each group (control, estrogen, physostigmine, and physostigmine + BIBN 99) is summarized in Table 1.

\section{Experiment 3}

The following experiment was completed and then replicated with a separate set of animals. Data were combined for analyses.

Subjects. Forty Long-Evans hooded female rats were purchased at $60 \mathrm{~d}$ of age. At $70 \mathrm{~d}$ of age, all rats were placed on diets to maintain body weights at $90 \%$ of their free-feeding weights. Animals were allowed to gain an additional $5 \mathrm{gm}$ per week to account for normal growth.

Training procedures. Females were trained to obtain food rewards (Kellogg's Froot Loops) from the arms of an elevated eight-arm radial maze obtained commercially from Lafayette Instruments (Lafayette, IN). The maze consisted of black metal floors and clear Plexiglas walls. The eight arms $(10 \mathrm{~cm}$ wide $\times 70 \mathrm{~cm}$ long $\times 20 \mathrm{~cm}$ high $)$ were separated from an octagonal center compartment $(33 \mathrm{~cm}$ across) by guillotine doors that could be opened or closed silently by mechanical relay. The room in which the maze was located contained fixed extramaze cues. To begin each training trial, the rat was placed in the center compartment of the maze with the doors of the arms closed. All doors then were opened, and the rat was allowed to enter any of the eight arms. The experimenter, who was seated in the room at a fixed location $\sim 5$ feet from the maze, recorded arm choices. An arm choice was scored if the rat traveled halfway down the length of an arm. An error was scored if a rat reentered an arm visited previously. The rat was allowed to choose arms in any order until all arms were visited or until $5 \mathrm{~min}$ had elapsed. Beginning on the sixth training trial, the animal was removed from the maze after it had made four correct arm choices and placed in a holding cage for a period of $1 \mathrm{~min}$. It then was returned to the center compartment of the maze with all arms opened and allowed to choose arms in any order until all arms were visited or until a total of 6 min had elapsed. This training procedure was used to acclimate the animal to the test trial procedure, in which a longer delay was instituted between the fourth and fifth arm 


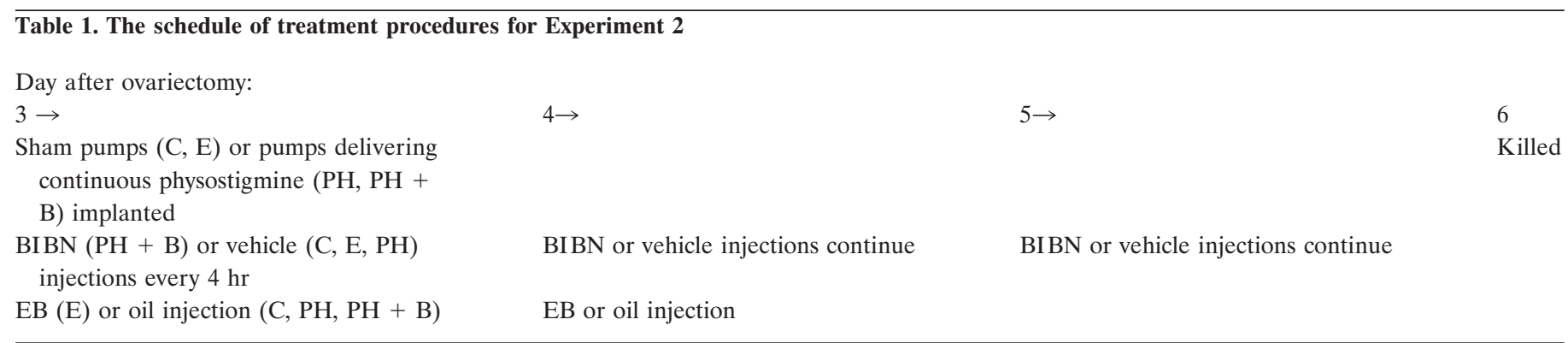

C, Control; E, estrogen; EB, estradiol benzoate; $\mathrm{PH}$, physostigmine; $\mathrm{PH}+\mathrm{B}$, physostigmine $+\mathrm{BIBN} 99$.

choices. Accuracy was scored by two measures, the number of correct choices until the first error and the number of correct choices in the first eight visits.

Rats were trained on the task for one trial per day for $18 \mathrm{~d}$, at which time all females had reached a criterion of $80 \%$ correct averaged over three consecutive training trials. At that point, animals were ovariectomized and randomly assigned to one of the following groups $(n=9)$ : (1) control, (2) estrogen, (3) estrogen + BIBN 99, or (4) BIBN 99. After ovariectomy, animals were trained on the maze every other day until testing to maintain performance levels.

Treatments. On days 3 and 4 after ovariectomy, animals assigned to the estrogen and the estrogen + BIBN 99 groups were injected intramuscularly with $10 \mu \mathrm{g}$ of estradiol benzoate in $0.1 \mathrm{ml}$ of cottonseed oil vehicle. Animals in the other two groups were injected with $0.1 \mathrm{ml}$ of vehicle alone. At the time of the first injection of estradiol or oil, animals assigned to estrogen + BIBN 99 and to BIBN 99 were also injected with BIBN 99 (0.05 mg/kg, s.c.) delivered in $4.2 \%$ aqueous D-mannitol solution. Animals in the other two groups were injected with vehicle alone. Additional injections of BIBN 99 or vehicle were given every $4 \mathrm{hr}$ until testing. Approximately $48 \mathrm{hr}$ after the second estradiol or oil injection, animals were tested on the eight-arm radial maze.

Testing procedures. The test trial was conducted in a manner identical to that of the training trials with one exception. After the animal made four correct arm choices, it was removed from the maze and placed in a holding cage for $3 \mathrm{hr}$. It then was returned to the maze to complete the test trial.

Summary. The schedule of training, treatment, and testing procedures for each group (control, estrogen, estrogen + BIBN 99, and BIBN 99) is summarized in Table 2.

\section{Experiment 4}

Immediately after testing on the radial maze, rats from the first replication of Experiment 3 were killed $(n=9)$, and NMDA receptor binding in area CA1 of the dorsal hippocampus was determined by quantitative receptor autoradiography as described in Experiment 1.

\section{RESULTS}

\section{Experiment 1}

The goal of the first experiment was to determine whether elevating endogenous levels of acetylcholine in ovariectomized rats via administration of physostigmine, an acetylcholinesterase inhibitor, would increase NMDA receptor binding in CA1 of the hippocampus. Figures 1 and 2 illustrate that ovariectomized rats receiving $3 \mathrm{~d}$ of treatment with physostigmine at 0.06 $\mathrm{mg} \cdot \mathrm{kg}^{-1} \cdot \mathrm{hr}^{-1}$, a dose demonstrated to cause near-maximal inhibition of cortical acetylcholinesterase activity (Mandel et al., 1989), displayed increased NMDA receptor binding in CA1 of the hippocampus compared with ovariectomized controls. To determine the effect of treatment as well as to determine whether the effect of treatment varied across the hemisphere, data collected from autoradiograms were analyzed by two-way ANOVA (treatment $\times$ hemisphere). A significant main effect of treatment was revealed $\left(F_{(2,44)}=3.246 ; p<0.05\right)$. Post hoc comparisons indicated that animals that received physostigmine at 0.06 $\mathrm{mg} \cdot \mathrm{kg}^{-1} \cdot \mathrm{hr}^{-1}$, but not those that received 0.0075 $\mathrm{mg} \cdot \mathrm{kg}^{-1} \cdot \mathrm{hr}^{-1}$, displayed significantly higher NMDA receptor binding than did controls (Newman-Keuls, $p<0.05$ ). No effect of hemisphere or interaction of treatment and hemisphere was revealed.

\section{Experiment 2}

The results of Experiment 1 demonstrated that elevating endogenous levels of acetylcholine in ovariectomized rats via continuous administration of physostigmine for $3 \mathrm{~d}$ increased NMDA receptor binding in CA1 of the hippocampus. The first objective of Experiment 2 was to compare the effects of physostigmine and estrogen on NMDA receptor binding. The second objective of Experiment 2 was to determine whether acetylcholine acts at M2 muscarinic receptors to increase NMDA binding in CA1. Specifically, we determined whether systemic administration of an M2 muscarinic receptor antagonist would block the physostigmine-induced increase in NMDA receptor binding. The M2 muscarinic antagonist 5,11-dihydro-8-chloro-11-[[4-[3-[(2,2-dimethyl-1-oxopentyl) ethylamino]propyl]-1-piperidinyl]acetyl]-6H-pyrido[2,3-b][1,4] benzodiazepin-6-one (BIBN 99), was used because it exhibits a high affinity for rat cardiac $\mathrm{M} 2$ sites $\left(\mathrm{IC}_{50}, 30 \mathrm{~nm}\right)$ and a low affinity for rat cortical $\mathrm{M} 1$ ( $\left.\mathrm{IC}_{50}, 676 \mathrm{~nm}\right)$ and rat submandibular M3 ( $\left.\mathrm{IC}_{50}, 690 \mathrm{~nm}\right)$ (Doods et al., 1993) sites. Figure 3 illustrates that ovariectomized rats treated with either estrogen or physostigmine alone exhibited a significant increase in NMDA receptor

\section{Table 2. The schedule of training, treatment, and test procedures for Experiment 3}

Day

$1 \rightarrow$

Maze

training

begins
$18 \rightarrow$

Ovariectomy
$21 \rightarrow$

$\mathrm{EB}(\mathrm{E}, \mathrm{E}+\mathrm{B})$ or oil

$(\mathrm{C}, \mathrm{B})$ injection

$\mathrm{BIBN}(\mathrm{E}+\mathrm{B}, \mathrm{B})$ or

vehicle $(C, E)$ injec-

tions every $4 \mathrm{hr}$
$22 \rightarrow$

EB or oil injection

BIBN or vehicle injections continue
$23 \rightarrow$

Test

24

$\mathrm{BIBN}$ or vehicle injections continue 
A. CONTROL
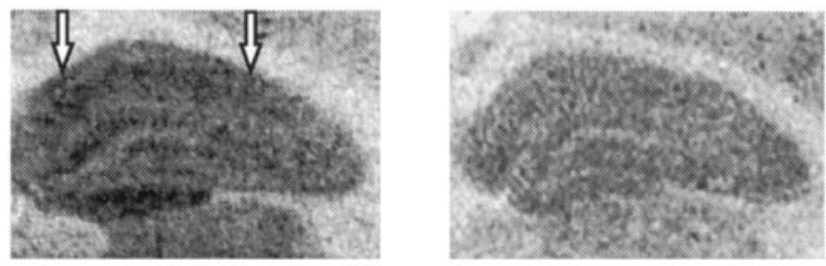

B. PHYSOSTIGMINE, $0.0075 \mathrm{mg} / \mathrm{kg} / \mathrm{hr}$
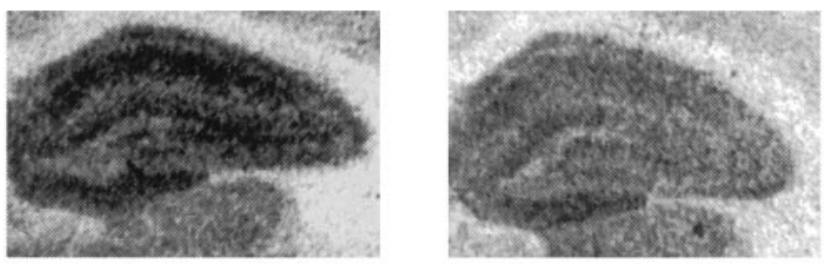

\section{PHYSOSTIGMINE, $0.06 \mathrm{mg} / \mathrm{kg} / \mathrm{hr}$}
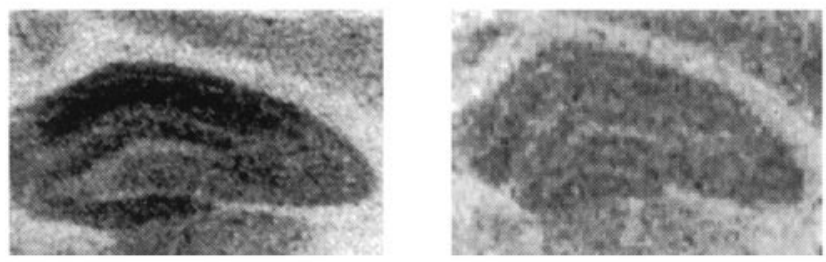

Figure 1. Representative autoradiograms of $\left[{ }^{3} \mathrm{H}\right]$ glutamate binding in the dorsal hippocampus in brains taken from ovariectomized rats receiving control treatment $(A), 3 \mathrm{~d}$ of chronic treatment of physostigmine at $0.0075 \mathrm{mg} \cdot \mathrm{kg}^{-1} \cdot \mathrm{hr}^{-1}(B)$, or $3 \mathrm{~d}$ of chronic treatment of physostigmine at $0.06 \mathrm{mg} \cdot \mathrm{kg}^{-1} \cdot \mathrm{hr}^{-1}(C)$. Left panels illustrate total $\left[{ }^{3} \mathrm{H}\right]$ glutamate binding, and right panels illustrate $\left[{ }^{3} \mathrm{H}\right]$ glutamate binding that remained in the presence of NMDA. NMDA binding was taken to be the amount of total $\left[{ }^{3} \mathrm{H}\right]$ glutamate binding displaced by NMDA (difference between left and right panels). Arrows indicate the area in which measurements were taken.

binding in CA1 of the hippocampus compared with ovariectomized controls. Animals that were treated with the M2 muscarinic receptor antagonist $\mathrm{BIBN} 99$ along with physostigmine did not exhibit this increase in NMDA receptor binding. Binding values expressed in picomoles per milligram of protein were analyzed by two-way ANOVA (treatment $\times$ hemisphere). There was a significant main effect of treatment $\left(F_{(3,54)}=3.826 ; p<\right.$ 0.02). Post hoc comparisons indicated that animals that received either estrogen or physostigmine alone, but not those that received physostigmine + BIBN 99, displayed significantly higher NMDA receptor binding than did controls (Newman-Keuls, $p<$ $0.05)$. No effect of hemisphere or interaction of hemisphere with treatment was found.

\section{Experiment 3}

The first objective of Experiment 3 was to determine whether the regimen of estradiol replacement demonstrated previously to induce formation of new dendritic spines (Gould et al., 1990; Woolley et al., 1997) and to increase NMDA receptor binding in CA1 (see Results of Experiment 2) (see also Woolley et al., 1997) would enhance performance on a task of working memory. The second objective was to determine whether an estradiol-induced enhancement of working memory was mediated by the action of acetylcholine on M2 receptors. Specifically, the effects of systemic injections of estradiol given to ovariectomized rats 72 and $48 \mathrm{hr}$

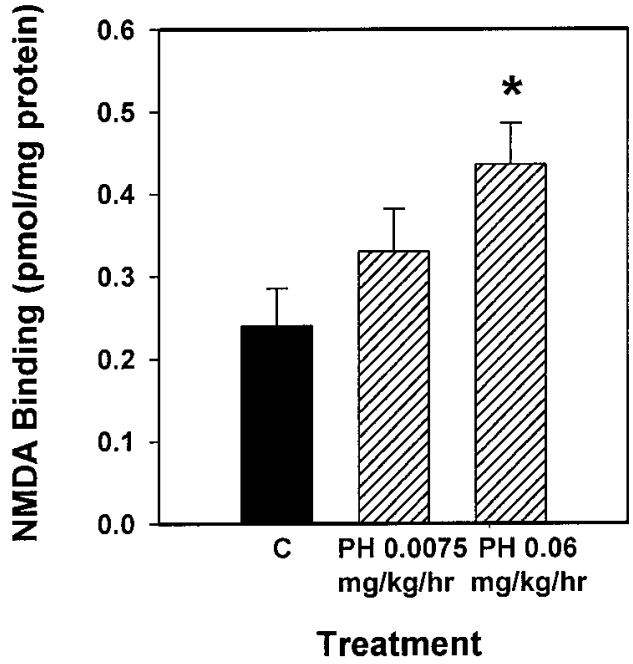

Figure 2. Effect of the acetylcholinesterase inhibitor physostigmine on NMDA-displaceable $\left[{ }^{3} \mathrm{H}\right]$ glutamate binding in CA1 of the dorsal hippocampus of ovariectomized rats. Osmotic minipumps delivered physostigmine $(P H)$ for $3 \mathrm{~d}$ at constant rates of 0.0075 or 0.06 $\mathrm{mg} \cdot \mathrm{kg}^{-1} \cdot \mathrm{hr}^{-1}$. After death, NMDA receptor binding was determined via in vitro quantitative receptor autoradiography. Values reported are total $\left[{ }^{3} \mathrm{H}\right]$ glutamate binding minus $\left[{ }^{3} \mathrm{H}\right]$ glutamate binding in the presence of NMDA (in pmol/mg protein \pm SEM). Data were collected from 12 consecutive sections of the dorsal hippocampus between 2.56 and $2.80 \mathrm{~mm}$ posterior to bregma [ ${ }^{*} p<0.05$ vs control $(C)$; Newman-Keuls].

before testing on an eight-arm radial maze were assessed, and it was determined whether chronic administration of BIBN 99, an M2 antagonist, would counteract the effects of estradiol on working memory performance. Figure $4 A$ illustrates that ovariectomized rats treated with two injections of estradiol 72 and $48 \mathrm{hr}$ before testing displayed enhanced working memory performance on the eight-arm radial maze compared with estradiol-treated animals also treated with BIBN 99, animals treated with BIBN 99 alone, and ovariectomized controls. Choice accuracy data collected on the test trial were analyzed by a one-way ANOVA (treatment) followed by post hoc comparisons. There was a significant main effect of treatment $\left(F_{(3,64)}=7.752 ; p<0.01\right)$, for the number of correct choices until the first error (Fig. 4A). Animals treated with estradiol alone made significantly more correct arm choices until the first error than did animals treated with estradiol + BIBN 99, animals treated with BIBN 99 alone, or control animals (Newman-Keuls, $p<0.05$ ). There was also a significant main effect of treatment $\left(F_{(3,64)}=2.910 ; p<0.01\right)$, for the number correct in the first eight visits (Fig. $4 B$ ). Animals treated with estradiol alone made significantly more correct arm choices in the first eight visits than did animals treated with BIBN 99 alone (Newman-Keuls, $p<0.05$ ). However, no other significant group differences were revealed for this measure of armchoice accuracy.

\section{Experiment 4}

In Experiment 4, NMDA receptor binding was measured in brains taken from rats used in behavior testing in Experiment 3. The objective of Experiment 4 was to determine whether acetylcholine mediates the estradiol-induced increase in NMDA receptor binding by acting at M2 receptors. Therefore, it was determined whether administration of BIBN 99, the M2 antagonist, would block the estradiol-induced increase in NMDA receptor binding in CA1 of the hippocampus. Additionally, it was deter- 


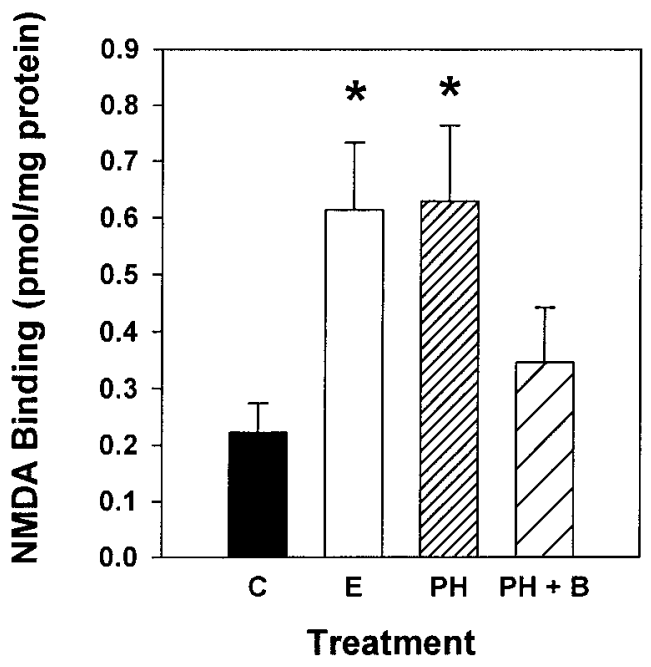

Figure 3. Effects of estrogen, physostigmine, and physostigmine plus the M2 muscarinic receptor antagonist BIBN 99 on NMDA-displaceable $\left[{ }^{3} \mathrm{H}\right]$ glutamate binding in CA1. Ovariectomized rats received one of the following treatments: control treatment $(C)$, two injections of estradiol benzoate $(10 \mu \mathrm{g})$ delivered at 72 and $48 \mathrm{hr}$ before death $(E), 3 \mathrm{~d}$ of continuous treatment of physostigmine $\left(0.06 \mathrm{mg} \cdot \mathrm{kg}^{-1} \cdot \mathrm{hr}^{-1} ; P H\right)$, or $3 \mathrm{~d}$ of continuous treatment of physostigmine plus injections of BIBN $99(0.05$ $\mathrm{mg} / \mathrm{kg}$, delivered every $4 \mathrm{hr} ; P H+B)$. After death, NMDA receptor binding was determined via in vitro quantitative receptor autoradiography. Values reported are total $\left[{ }^{3} \mathrm{H}\right]$ glutamate binding minus $\left[{ }^{3} \mathrm{H}\right]$ glutamate binding in the presence of NMDA (in $\mathrm{pmol} / \mathrm{mg}$ protein $\pm \mathrm{SEM}$ ). Data were collected from 12 consecutive sections of the dorsal hippocampus between 2.56 and $2.80 \mathrm{~mm}$ posterior to bregma $\left({ }^{*} p<0.05\right.$ vs $C$; Newman-Keuls).

mined whether BIBN 99 administered alone would affect NMDA receptor binding in CA1. Figure 5 illustrates that ovariectomized rats treated with estrogen exhibited a significant increase in NMDA receptor binding in CA1 of the hippocampus compared with estradiol-treated animals that also were treated with BIBN 99 and ovariectomized controls. Data collected from autoradiograms were analyzed by two-way ANOVA (treatment $\times$ hemisphere). A significant main effect of treatment was revealed $\left(F_{(3,56)}=3.559 ; p<0.02\right)$. Post hoc comparisons revealed that females that received estrogen alone displayed significantly higher NMDA receptor binding than did control animals and those that were treated with estrogen and BIBN 99 (NewmanKeuls, $p<0.05)$. There was no significant effect of hemisphere and no interaction of hemisphere and treatment.

\section{DISCUSSION}

The results of the present experiments indicate that acetylcholine, acting at M2 muscarinic receptors, plays a role in the estradiol-induced increase in NMDA receptor binding in CA1 of the dorsal hippocampus as well as in the associated enhancement of performance on a working memory task. In Experiment 1, elevating endogenous levels of acetylcholine in ovariectomized rats by continuous administration of physostigmine, an acetylcholinesterase inhibitor, increased NMDA receptor binding in CA1. In Experiment 2, it was further shown that the increase in NMDA receptor binding in CA1 induced by physostigmine was comparable with the increase induced by estrogen. Additionally, the administration of BIBN 99, an M2 muscarinic receptor antagonist, prevented the increase in NMDA receptor binding induced by physostigmine. In Experiment 3, the regimen of estradiol replacement shown to increase NMDA receptor binding
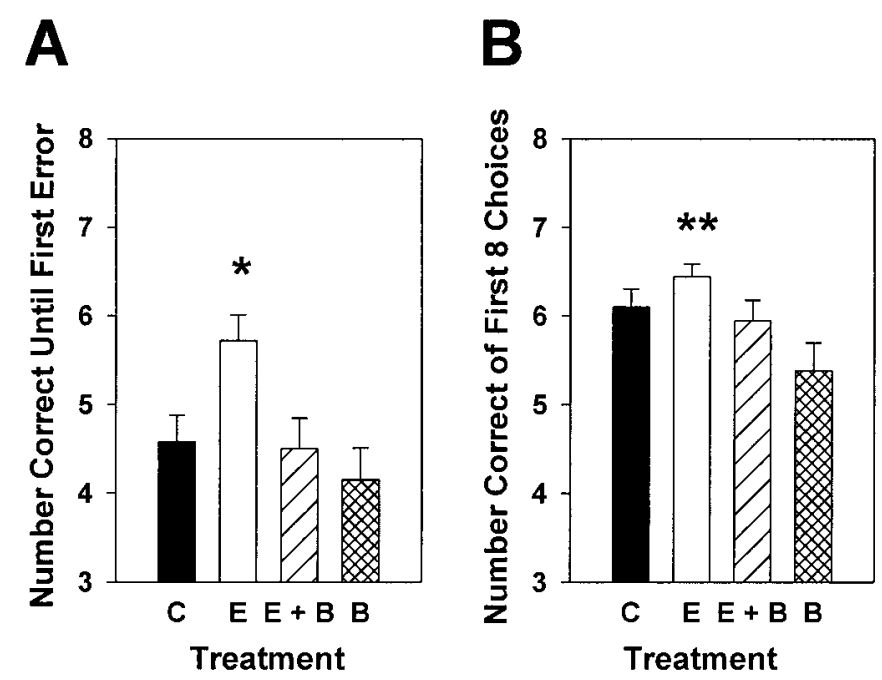

Figure 4. Effects of estrogen, estrogen plus the M2 receptor antagonist BIBN 99, or BIBN 99 alone on working memory performance in an eight-arm radial maze. Female rats were trained to obtain food rewards from the arms of the maze with all arms baited. For the training trials, a 1 min delay was instituted between the fourth and fifth arm choices. After $18 \mathrm{~d}$ of training, all rats were ovariectomized and randomly assigned to receive one of the following treatments: control treatment $(C)$, two injections of estradiol benzoate $(10 \mu \mathrm{g})$ delivered 72 and $48 \mathrm{hr}$ before death $(E)$, two injections of estradiol benzoate plus injections of BIBN 99 $(0.05 \mathrm{mg} / \mathrm{kg}$, delivered every $4 \mathrm{hr} ; E+B)$, or injections of BIBN 99 alone $(B)$. Two separate replications of the experiment were completed, and data were combined for analyses. Data presented are from the test trial in which a $3 \mathrm{hr}$ delay was instituted between the fourth and fifth arm choices. $A$, Mean number of correct arm choices ( \pm SEM) before the first error (* $p<0.05$ vs $C, E+B, B$; Newman-Keuls). $B$, Mean number of correct arm choices $( \pm \mathrm{SEM})$ in the first eight visits $\left({ }^{*} p<0.05\right.$ vs $B$; Newman-Keuls).

in CA1 also enhanced working memory performance as assessed in an eight-arm radial maze. In addition, this estradiol-induced enhancement in performance was blocked by administration of BIBN 99. Finally, in Experiment 4, estrogen treatment increased NMDA receptor binding in CA1 in brains taken from animals immediately after maze testing in Experiment 3, an increase that was prevented by systemic administration of BIBN 99 .

The present results demonstrate that the ability of estrogen to effect change in NMDA receptor binding in CA1 is related to its ability to alter cholinergic neurochemistry. In a previous report, the muscarinic receptor antagonist scopolamine failed to block the estradiol-induced increase in spine density in ovariectomized rats (Woolley and McEwen, 1994). However, in that experiment scopolamine was administered every $12 \mathrm{hr}$. Because scopolamine has a half-life of $<30 \mathrm{~min}$ in rats (Lyeth et al., 1992), it may have been unable to block muscarinic receptors during a significant portion of the period of estrogen exposure. In the present study, continuous release of physostigmine mimicked the effect of estradiol on levels of NMDA receptor binding in CA1, an effect that was demonstrated across two experiments.

The results of the current experiments indicate that acetylcholine acts at the M2 subtype of the muscarinic receptor to affect levels of NMDA receptor binding in CA1. Although the specific mechanisms by which increased levels of acetylcholine act at M2 muscarinic receptors to increase NMDA receptor binding cannot be determined from the results of the present experiments, there are interesting possibilities. Cholinergic neurons in the medial septal/diagonal band complex contain estrogen receptors (Shugh- 


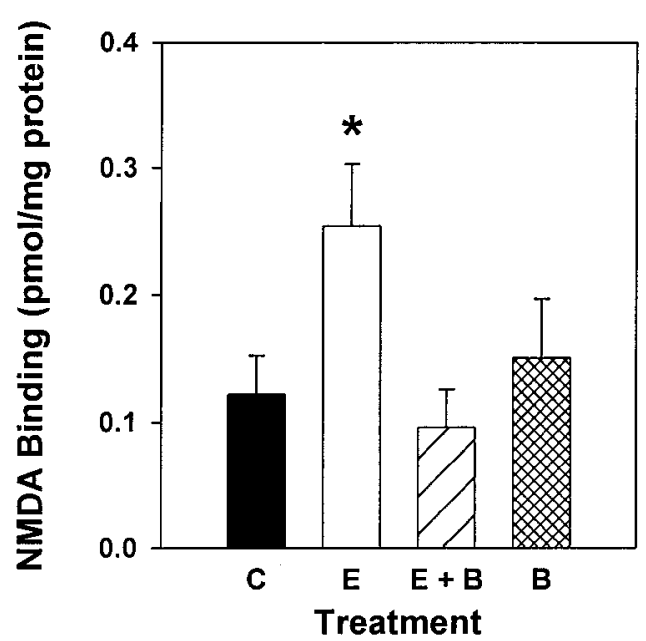

Figure 5. Effects of estrogen, estrogen plus the M2 receptor antagonist BIBN 99, or BIBN 99 alone on NMDA-displaceable $\left[{ }^{3} \mathrm{H}\right]$ glutamate binding in CA1. Ovariectomized rats received one of the following treatments: control treatment $(C)$, two injections of estradiol benzoate $(10 \mu \mathrm{g})$ delivered 48 and $72 \mathrm{hr}$ before death $(E)$, two injections of estradiol benzoate plus injections of BIBN $99(0.05 \mathrm{mg} / \mathrm{kg}$, delivered every $4 \mathrm{hr} ; E+B$ ), or injections of BIBN 99 alone $(B)$. After death, NMDA receptor binding was determined via in vitro quantitative receptor autoradiography. Values reported are total $\left[{ }^{3} \mathrm{H}\right]$ glutamate binding minus $\left[{ }^{3} \mathrm{H}\right.$ ]glutamate binding in the presence of NMDA (in $\mathrm{pmol} / \mathrm{mg}$ protein \pm SEM). Data were collected from 12 consecutive sections of the dorsal hippocampus between 2.56 and $2.80 \mathrm{~mm}$ posterior to bregma $\left({ }^{*} p<0.05\right.$ vs $C, E+B$; Newman-Keuls).

rue et al., 2000). Estrogen could act on these receptors to increase acetylcholine release in projection sites in the hippocampus. Increased levels of acetylcholine could act at M2 muscarinic receptors located on the axon terminals of GABAergic basket cells located in the pyramidal cell layer of Ammon's horn (Freund and Gulyas, 1997; Hajos et al., 1998). These GABA interneurons provide powerful somatic inhibition to hippocampal pyramidal cells. The action of acetylcholine at the M2 receptors is to inhibit the release of GABA. Thus, an estradiol-induced increase in levels of acetylcholine would increase action at these M2 receptors, resulting in increased inhibition of GABA release leading to disinhibition of the pyramidal cells, a step demonstrated to lead to morphological changes in CA1 (Murphy and Segal, 1997).

As an alternative, but not mutually exclusive, hypothesis, increased levels of acetylcholine induced by physostigmine or estrogen could act at M2 receptors located in the medial septal region and diagonal band complex, resulting in disinhibition of pyramidal cells of the hippocampus. In the basal forebrain, the M2 subtype of the muscarinic receptor is localized to dendrites and somata of noncholinergic neurons, at least some of which contribute to the GABAergic component of the septohippocampal pathway (Levey et al., 1995). GABAergic input from the septum, by exclusively targeting GABA interneurons in the hippocampus, regulates GABAergic inhibition of hippocampal principal cells (Freund and Antal, 1988). Locally released acetylcholine in the medial septal/diagonal band complex provides a strong excitatory drive to GABA neurons in the septohippocampal pathway (Alreja et al., 2000). In the present study, elevating endogenous levels of acetylcholine via systemic administration of estradiol or physostigmine most likely stimulated M2 receptors in the basal forebrain, resulting in increased excitation in the GABAergic inputs to the hippocampus. The resultant inhibition of hippocampal GABA interneurons would contribute to disinhibition of the pyramidal cells. Blocking the M2 muscarinic receptors in the medial septal region and diagonal band complex could, at least partly, be responsible for the ability of BIBN 99 to counteract the effects of physostigmine and estradiol on CA1 NMDA receptor binding. Clearly, further work is needed to identify the specific mechanisms by which acetylcholine acts at the M2 subtype of the muscarinic receptor to increase NMDA receptor binding in CA1 of the hippocampus. In addition, it is important to note that it is currently unknown whether the mechanism by which estrogen increases CA1 NMDA receptor binding is the same as the mechanism by which estrogen induces parallel increases in CA1 dendritic spine and synapse density (Gould et al., 1990; Woolley et al., 1997). Furthermore, although acetylcholine acts at $\mathrm{M} 2$ receptors to increase NMDA receptor binding in CA1, the possible increases in spine and synapse density of CA1 pyramidal cells induced by acetylcholine have not been investigated.

Although the present results indicate that estrogen interacts with the cholinergic system to increase NMDA binding in CA1, estrogen could also act via other mechanisms to influence NMDA receptor binding as well as spine and synapse density. For example, estrogen may act directly on hippocampal GABAergic interneurons to inhibit GABA activity and thus increase the excitatory drive on pyramidal cells, leading to morphological change in CA1 (Murphy et al., 1998). Immunoreactivity for the classical estrogen receptor $(\mathrm{ER}-\alpha)$ is expressed in GABAergic interneurons in the rat hippocampus (Weiland et al., 1997). In the dorsal hippocampus, levels of ER- $\alpha$ immunoreactivity were greatest in the dentate gyrus and stratum radiatum of CA1, although these levels were low in comparison with those of other brain regions such as the hypothalamus. Interestingly, in spite of the ability of estradiol to induce changes in GAD mRNA in the pyramidal cell layer of CA1 (Weiland, 1992b), there were few ER- $\alpha$ immunoreactive cells located in that region. However, results of an in situ hybridization study revealed that in addition to ER- $\alpha$ mRNA, the newly cloned estrogen receptor- $\beta$ (ER- $\beta$ ) mRNA is also expressed in the hippocampus. In recent autoradiographic studies, binding sites for ${ }^{125}$ I-estrogen, a ligand with a similar affinity for both ER- $\alpha$ and ER- $\beta$, were localized in the pyramidal cells of CA1CA3, with the highest levels of binding in the ventral portion of CA2 and CA3 (Shughrue et al., 1997; Shughrue and Merchenthaler, 2000). The roles of ER- $\alpha$ and ER- $\beta$ in the regulation of GABAergic synapses have yet to be determined.

An important finding of the experiments in the present study is that the changes in NMDA receptor binding in CA1 after acute estrogen treatment were associated with an enhancement in working memory performance in an eight-arm radial maze. In addition, the M2 muscarinic receptor antagonist BIBN 99 was able to counteract the estrogen-induced enhancement in working memory performance. In a previous study, no differences in working memory performance during the acquisition of an eightarm radial maze were found across the estrous cycle (Stackman et al., 1997). Taken together, these results indicate that the increase in spine and synapse density and the associated increase in NMDA receptor binding that occurs as a result of acute estrogen replacement may contribute to improvements in working memory performance in ovariectomized rats. It remains to be determined whether increases in spine and synapse density and NMDA receptor binding in CA1 are associated with improvements in working memory performance that have been demonstrated to occur after a regimen of chronic estrogen replacement (Daniel et al., 1997; Luine et al., 1998; Gibbs, 1999, 2000).

Although not directly related to the objectives of the present 
study, these results provide information as to the effect of an M2 muscarinic receptor antagonist on learning and memory performance. In previous studies, administration of BIBN 99 improved performance on a reference memory task in the Morris water maze in aged memory-impaired (Quirion et al., 1995) and traumatic brain-injured rats (Pike and Hamm, 1995). In contrast, on a task of working memory in a T maze, intrahippocampal administration of the putative M2 antagonist gallamine impaired performance (Messer and Miller, 1988). In the present study, there was not a significant difference in working memory performance between ovariectomized rats treated with BIBN 99 and ovariectomized controls. However, ovariectomized rats treated with estrogen significantly outperformed ovariectomized rats treated with BIBN 99 on a working memory task in the radial arm maze.

In conclusion, the results of the present experiments suggest for the first time a mechanism by which elevated levels of estrogen can lead to increased levels of NMDA receptor binding in CA1 of the hippocampus. Specifically, our results indicate that acetylcholine acts at the M2 subtype of the muscarinic receptor to mediate the estradiol-induced increase in NMDA receptor binding. Importantly, these results also demonstrate that the estradiolinduced increase in NMDA receptor binding is associated with enhancement in working memory performance in an eight-arm radial maze.

\section{REFERENCES}

Alreja M, Wu M, Liu W, Atkins JB, Leranth C, Shanabrough M (2000) Muscarinic tone sustains impulse flow in the septohippocampal GABA but not cholinergic pathway: implications for learning and memory. J Neurosci 20:8103-8110.

Berry B, McMahan R, Gallagher M (1997) Spatial learning and memory at defined points of the estrous cycle: effects on performance of a hippocampal-dependent task. Behav Neurosci 111:267-274.

Bimonte HA, Denenberg VH (1999) Estradiol facilitates performance as working memory load increases. Psychoneuroendocrinology 24:161-173.

Chesler EJ, Juraska JM (2000) Acute administration of estrogen and progesterone impairs the acquisition of the spatial Morris water maze in ovariectomized rats. Horm Behav 38:234-242.

Cyr M, Ghribi O, Di Paolo T (2000) Regional and selective effects of oestradiol and progesterone on NMDA and AMPA receptors in the rat brain. J Neuroendocrinol 12:445-452.

Daniel JM, Fader AJ, Spencer AL, Dohanich GP (1997) Estrogen enhances performance of female rats during acquisition of a radial arm maze. Horm Behav 32:217-225.

Daniel JM, Roberts SL, Dohanich GP (1999) Effects of ovarian hormones and environment on radial maze and water maze performance of female rats. Physiol Behav 66:11-20.

Doods H, Entzeroth M, Ziegler H, Schiavi G, Engel W, Mihm G, Rudolf K, Eberlein W (1993) Characterization of BIBN 99: a lipophilic and selective muscarinic M2 receptor antagonist. Eur J Pharmacol 242:23-30.

Fader AJ, Hendricson AW, Dohanich GP (1998) Estrogen improves performance of reinforced T-maze alternation and prevents the amnestic effects of scopolamine administered systemically or intrahippocampally. Neurobiol Learn Mem 69:225-240.

Fader AJ, Johnson PE, Dohanich GP (1999) Estrogen improves working but not reference memory and prevents amnestic effects of scopolamine of a radial-arm maze. Pharmacol Biochem Behav 62:711-717.

Freund TF, Antal M (1988) GABA-containing neurons in the septum control inhibitory interneurons in the hippocampus. Nature 336:170-173.

Freund TF, Gulyas AI (1997) Inhibitory control of GABAergic interneurons in the hippocampus. Can J Physiol Pharmacol 75:479-487.

Galea LA, Kavaliers M, Ossenkopp KP, Hampson E (1995) Gonadal hormone levels and spatial learning performance in the Morris water maze in male and female meadow voles, Microtus pennsylvanicus. Horm Behav 29:106-125.

Gibbs RB (1999) Estrogen replacement enhances acquisition of a spatial memory task and reduces deficits associated with hippocampal muscarinic receptor inhibition. Horm Behav 36:222-233.

Gibbs RB (2000) Long-term treatment with estrogen and progesterone enhances acquisition of a spatial memory task by ovariectomized aged rats. Neurobiol Aging 21:107-116.

Gibbs RB, Pfaff DW (1992) Effects of estrogen and fimbria/fornix tran- section on p75NGFR and ChAT expression in the medial septum and diagonal band of Broca. Exp Neurol 116:23-39.

Gibbs RB, Wu D, Hersh LB, Pfaff DW (1994) Effects of estrogen replacement on the relative levels of choline acetyltransferase, trkA, and nerve growth factor messenger RNAs in the basal forebrain and hippocampal formation of adult rats. Exp Neurol 129:70-80.

Gibbs RB, Hashash A, Johnson DA (1997) Effects of estrogen on potassium-stimulated acetylcholine release in the hippocampus and overlying cortex of adult rats. Brain Res 749:143-146.

Gould E, Woolley CS, Frankfurt M, McEwen BS (1990) Gonadal steroids regulate dendritic spine density in hippocampal pyramidal cells in adulthood. J Neurosci 10:1286-1291.

Hajos N, Papp EC, Acsady L, Levey AI, Freund TF (1998) Distinct interneuron types express $\mathrm{m} 2$ muscarinic receptor immunoreactivity on their dendrites or axon terminals in the hippocampus. Neuroscience $82: 355-376$

Leranth C, Shanabrough M, Horvath TL (2000) Hormonal regulation of hippocampal spine synapse density involves subcortical mediation. Neuroscience 101:349-356.

Levey AI, Edmunds SM, Hersch SM, Wiley RG, Heilman CJ (1995) Light and electron microscopic study of $\mathrm{m} 2$ muscarinic acetylcholine receptor in the basal forebrain of the rat. J Comp Neurol 351:339-356.

Luine VN (1985) Estradiol increases choline acetyltransferase activity in specific basal forebrain nuclei and projection areas of female rats. Exp Neurol 89:484-490.

Luine VN, Richards ST, Wu VY, Beck KD (1998) Estradiol enhances learning and memory in a spatial memory task and effects levels of monoaminergic neurotransmitters. Horm Behav 34:149-162.

Lyeth BG, Ray M, Hamm RJ, Schnabel J, Saady JJ, Poklis A, Jenkins LW, Gudeman SK, Hayes RL (1992) Postinjury scopolamine administration in experimental traumatic brain injury. Brain Res 569:281-286.

Mandel RJ, Chen AD, Connor DJ, Thal LJ (1989) Continuous physostigmine infusion in rats with excitotoxic lesions of the nucleus basalis magnocellularis: effects on performance in the water maze task and cortical cholinergic markers. J Pharmacol Exp Ther 251:612-619.

Messer Jr WS, Miller MD (1988) Intrahippocampal injections of gallamine impair learning of a memory task. Neurosci Lett 89:367-372.

Miller MM, Hyder SM, Assayag R, Panarella SR, Tousignant P, Franklin KB (1999) Estrogen modulates spontaneous alternation and the cholinergic phenotype in the basal forebrain. Neuroscience 91:1143-1153.

Murphy DD, Segal M (1996) Regulation of dendritic spine density in cultured rat hippocampal neurons by steroid hormones. J Neurosci 16:4059-4068

Murphy DD, Segal M (1997) Morphological plasticity of dendritic spines in central neurons is mediated by activation of cAMP response element binding protein. Proc Natl Acad Sci USA 94:1482-1487.

Murphy DD, Cole NB, Greenberger V, Segal M (1998) Estradiol increases dendritic spine density by reducing GABA neurotransmission in hippocampal neurons. J Neurosci 18:2550-2559.

O’Malley CA, Hautamaki RD, Kelley M, Meyer EM (1987) Effects of ovariectomy and estradiol benzoate on high affinity choline uptake, $\mathrm{ACh}$ synthesis, and release from rat cerebral cortical synaptosomes. Brain Res 403:389-392.

O’Neal MF, Means LW, Poole MC, Hamm RJ (1996) Estrogen affects performance of ovariectomized rats in a two-choice water-escape working memory task. Psychoneuroendocrinology 21:51-65.

Paxinos G (1995) The rat nervous system. San Diego: Academic.

Paxinos G, Watson C (1998) The rat brain in stereotaxic coordinates. San Diego: Academic.

Pike BR, Hamm RJ (1995) Post-injury administration of BIBN 99, a selective muscarinic M2 receptor antagonist, improves cognitive performance following traumatic brain injury in rats. Brain Res 686:37-43.

Quirion R, Wilson A, Rowe W, Aubert I, Richard J, Doods H, Parent A, White N, Meaney MJ (1995) Facilitation of acetylcholine release and cognitive performance by an $\mathrm{M}(2)$-muscarinic receptor antagonist in aged memory-impaired. J Neurosci 15:1455-1462.

Shughrue PJ, Merchenthaler I (2000) Evidence for novel estrogen binding sites in the rat hippocampus. Neuroscience 99:605-612.

Shughrue PJ, Lane MV, Merchenthaler I (1997) Comparative distribution of estrogen receptor-alpha and -beta mRNA in the rat central nervous system. J Comp Neurol 388:507-525.

Shughrue PJ, Scrimo PJ, Merchenthaler I (2000) Estrogen binding and estrogen receptor characterization (ERalpha and ERbeta) in the cholinergic neurons of the rat basal forebrain. Neuroscience 96:41-49.

Singh M, Meyer EM, Millard WJ, Simpkins JW (1994) Ovarian steroid deprivation results in a reversible learning impairment and compromised cholinergic function in female Sprague-Dawley rats. Brain Res 644:305-312.

Stackman RW, Blasberg ME, Langan CJ, Clark AS (1997) Stability of spatial working memory across the estrous cycle of Long-Evans rats. Neurobiol Learn Mem 67:167-171.

Warren SG, Juraska JM (1997) Spatial and nonspatial learning across the rat estrous cycle. Behav Neurosci 111:259-266.

Weiland NG (1992a) Estradiol selectively regulates agonist binding sites 
on the $N$-methyl-D-aspartate receptor complex in the CA1 region of the hippocampus. Endocrinology 131:662-668.

Weiland NG (1992b) Glutamic acid decarboxylase messenger ribonucleic acid is regulated by estradiol and progesterone in the hippocampus. Endocrinology 131:2697-2702.

Weiland NG, Orikasa C, Hayashi S, McEwen BS (1997) Distribution and hormone regulation of estrogen receptor immunoreactive cells in the hippocampus of male and female rats. J Comp Neurol 388:603-612.

Wilson IA, Puolivali J, Heikkinen T, Riekkinen Jr P (1999) Estrogen and NMDA receptor antagonism: effects upon reference and working memory. Eur J Pharmacol 381:93-99.

Wolff SC, Gallogy PM, Dohanich GP (1997) Asymmetric distribution of muscarinic receptors in the hippocampus of female rats. Soc Neurosci Abstr 23:58813.

Woolley CS, McEwen BS (1994) Estradiol regulates hippocampal dendritic spine density via an $N$-methyl-D-aspartate receptor-dependent mechanism. J Neurosci 14:7680-7687.

Woolley CS, Gould E, Frankfurt M, McEwen BS (1990) Naturally occurring fluctuation in dendritic spine density on adult hippocampal pyramidal neurons. J Neurosci 10:4035-4039.

Woolley CS, Weiland NG, McEwen BS, Schwartzkroin PA (1997) Estradiol increases the sensitivity of hippocampal CA1 pyramidal cells to NMDA receptor-mediated synaptic input: correlation with dendritic spine density. J Neurosci 17:1848-1859. 